\title{
Whole Organism Cloning
}

National Cancer Institute

\section{Source}

National Cancer Institute. Whole Organism Cloning. NCI Thesaurus. Code C19126.

Propagation of an entire organism from somatic cell material. It was first accomplished in the 50's using frog embryonic tissues. In 1997 researchers in Scotland announced the cloning of a sheep, Dolly, using adult mammary cell DNA as the starting material. Since then several other species have been successfully cloned, including cows, mice, and monkeys. 